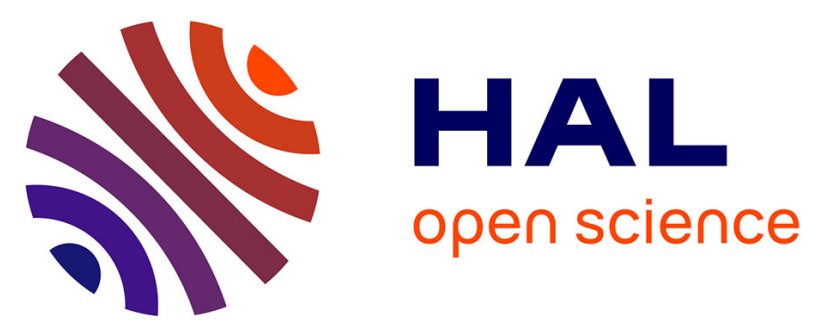

\title{
LASER MELTING TREATMENT BY OVERLAPPING PASSES OF PREHEATED NICKEL ELECTRODEPOSITED COATINGS ON Al-Si ALLOY
}

D. Pantelis, A. Houndri, S. Polymenis, Y. Chryssoulakis

\section{- To cite this version:}

D. Pantelis, A. Houndri, S. Polymenis, Y. Chryssoulakis. LASER MELTING TREATMENT BY OVERLAPPING PASSES OF PREHEATED NICKEL ELECTRODEPOSITED COATINGS ON Al-Si ALLOY. Journal de Physique IV Proceedings, 1991, 01 (C7), pp.C7-111-C7-116. 10.1051/jp4:1991723 . jpa-00250926

\section{HAL Id: jpa-00250926 https://hal.science/jpa-00250926}

Submitted on 1 Jan 1991

HAL is a multi-disciplinary open access archive for the deposit and dissemination of scientific research documents, whether they are published or not. The documents may come from teaching and research institutions in France or abroad, or from public or private research centers.
L'archive ouverte pluridisciplinaire HAL, est destinée au dépôt et à la diffusion de documents scientifiques de niveau recherche, publiés ou non, émanant des établissements d'enseignement et de recherche français ou étrangers, des laboratoires publics ou privés. 


\title{
LASER MELTING TREATMENT BY OVERLAPPING PASSES OF PREHEATED NICKEL ELECTRODEPOSITED COATINGS ON AI-Si ALLOY
}

\author{
D. PANTELIS, A. HOUNDRI*, S. POLYMENIS* and Y. CHRYSSOULAKIS* \\ Laboratory MSS/MAT, URA CNRS n ${ }^{\circ} 850$, Ecole Centrale de Paris, Grande Voie des Vignes, \\ F-92295 Châtenay-Malabry cedex, France \\ *Laboratory of Physical Chemistry and Applied Electrochemistry, National Technical \\ University of Athens, 9 Iroon Polychniou Str., GR-15773 Zografou, Athens, Greece
}

\begin{abstract}
Microstructure improvements of a Nickel electrodeposited Al-Si alloy were studied after high power laser melting treatment through a single pass or partially overlapping successive adjacent passes. In some cases laser melting treatment was preceded by a 5-hours heating of the specimens at $500^{\circ} \mathrm{C}$ in an Argon atmosphere furnace. Best results concerning microhardness, microstructural homogeneity, porosity elimination as well as adhesion of the nickel coating on the Al-Si alloy were achieved when the speeimens were first subjected to heating at $500^{\circ} \mathrm{C}$ in an Argon atmosphere furnace for 5 hours and then submitted to a laser melting treatment through successive adjacent laser passes with an overlapping rate of $70 \%$.
\end{abstract}

\section{INTRODUCTION.}

There are only a few methods available which can improve the surface properties of the alloys while keeping their bulk properties intact. One of these methods is based on the use of a high power laser beam, by means of which it is possible to melt a predeposited layer on a metal surface containing a particular alloying element. The above methods, however, are reported to display certain problems such as the appearance of cracks, pores as well as structural or chemical heterogeneity in the laser melted zone (LMZ).

The purpose of the present work is to determine any possible improvements in the microstructure and consequently the properties of nickel coated Al-Si alloys after treatment by a high power laser beam.

The nickel electrodeposition was carried out on a rotating Al-Si cathode in a Watts-type bath. The laser melting process consisted of a single laser pass as well as partial overlap among successive adjacent laser passes. This was preceded by heating the specimens at $500^{\circ} \mathrm{C}$ in an Argon atmosphere furnace so that the nickel coating improves its porosity and adhesion.

\section{EXPERIMENTAL PROCEDURE.}

\section{II.1. Materials.}

A hypoeutectic AI-Si alloy (AS7G03) was employed. Its chemical composition is given below in Table 1.

Table 1. Chemical composition of alloy used

\begin{tabular}{|c|c|c|c|c|c|c|c|c|c|c|}
\hline $\begin{array}{c}\text { Element } \\
\text { wt\% }\end{array}$ & $\mathrm{Fe}$ & $\mathrm{Si}$ & $\mathrm{Cu}$ & $\mathrm{Mg}$ & $\mathrm{Mn}$ & $\mathrm{Ni}$ & $\mathrm{Zn}$ & $\mathrm{Ti}$ & $\mathrm{Pb}$ & $\mathrm{Sn}$ \\
\hline $\min$ & & 6.5 & & 0.25 & & & & 0.10 & & \\
\hline $\max$ & 0.2 & 7.5 & 0.10 & 0.40 & 0.10 & 0.05 & 0.10 & 0.20 & 0.05 & 0.05 \\
\hline
\end{tabular}

This alloy was prepared by casting a commercially available Al-Si ingot of AS7GO3 while adding NaF $(0,05$ to $0,08 \%$ $w / w)$ in order to refine the microstructure of the alloy. The cast product was cut so that the specimens have a disc form (Diameter: $30 \mathrm{~mm}$, Height: $3 \mathrm{~mm}$ ). 
II.2. Electroplating process.

Nickel electrodeposition was preceded by cleaning and conditioning treatments of the Al-Si alloy to provide uniform surface activity $[1,2]$.

Immediately afterwards the specimen was immersed in a Watts-type bath $\left(300 \mathrm{~g} / \mathrm{L} \mathrm{NiSO} 4 \cdot 7 \mathrm{H}_{2} \mathrm{O}, 35 \mathrm{~g} / \mathrm{L}\right.$ $\left.\mathrm{NiCl}_{2} \cdot 6 \mathrm{H}_{2} \mathrm{O}, 40 \mathrm{~g} / \mathrm{L} \mathrm{H}_{3} \mathrm{BO}_{3}\right)$ and it was attached to the cathode which started rotating $(1200 \mathrm{rpm})$. The exposed area of the specimen, that was to be electroplated, was a disc with a diameter of $20 \mathrm{~mm}$. Pure nickel was used as anode, which was covered by a poly-acrylic material leaving an exposed disc area with a diameter of $20 \mathrm{~mm}$.

The bath was operated at $50^{\circ} \mathrm{C}$, the current density was $12 \mathrm{Avdm}^{2}$ and the $\mathrm{pH}$ was 2.4 . The electrolysis duration was calculated according to Faraday's law and the current efficiency [3] so that the thickness of the deposit was 180 $\mu \mathrm{m}$.

\section{II.3. Laser melting process.}

The laser treatment was carried out by using a CILAS 4000 continuous $\mathrm{CO}_{2}$ laser beam (wavelength: $10.6 \mu \mathrm{m}$, maximum output power: 3.2. $\mathrm{kW}$ and annular beam energy distribution in TEM01 mode). A special optical set-up was invented to protect the $250 \mathrm{~mm}$ focal length lens [4].

Preliminary tests were carried out to determine the values of the parameters for the laser melting process so that the optimal track, concerning porosity and cracking, was obtained. The values of these parameters were the following:

- Incident power density: $Q=3 \cdot 10^{5} \mathrm{~W} / \mathrm{cm}^{2}$

- Interaction time: $t=66 \mathrm{~ms}$

The defocused distance $D_{\text {def }}$ remained constant and equal to $15 \mathrm{~mm}$. Argon was used as an inert gas protection. When the process was carried out by successive adjacent passes, the overlapping rate was $35 \%, 50 \%$ and $70 \%$.

\section{II.4. Heat treatment preceding the laser melting process.}

Before laser melting some specimens were heated at $500^{\circ} \mathrm{C}$ for 5 hours in a furnace in Argon atmosphere. This is the maximum temperature at which specimens can be heated without risking deformation of the substrate but mainly to remain under the Al-Si eutectic temperature $\left(577^{\circ} \mathrm{C}\right)$ and Al-Ni eutectic temperature $\left(640^{\circ} \mathrm{C}\right)$ [5] and so to avoid local melting.

This heat treatment was performed to improve the adhesion and to reduce the porosity of the deposited nickel layer, since the laser treatment eliminates only part of the pores.

\section{RESULTS AND DISCUSSION.}

\section{III.1. Macroscale observations.}

Adhesion was very poor before the laser treatment because of the initial condition of the substrate surface, the instantaneous alumina film formation and the negligible value of the interdiffusion coefficient due to the low electroplating temperature. After laser treatment, considerable porosity was observed in the laser melted zone near the interface between the laser melted zone and the substrate. This may be attributed to the following facts: a) substrate porosity resulting from casting, b) hydrogen adsorption during electrodeposition or from the air humidity during laser melting and c) argon adsorption from the protective atmosphere during the latter process [6, 7].

In order to eliminate the porosity, two further procedures were tested: laser overlapping passes and preheating. Laser melting through successive adjacent passes with an overlapping rate of $35 \%, 50 \%$ and $70 \%$ reduced the total volume of the pores and pushed them towards the edges of the laser melted zone. This may be attributed to the presence of convection currents in the laser molten pool.

This phenomenon was more pronounced when the overlapping rate was increased up to $70 \%$. A 5 hours preheating followed by a single laser pass reduced the number and size of the pores in the laser melted zone. This is probably due to the elimination of the gases during a process of sintering while heating. A 5 hours preheating followed by a process of laser overlapping passes completely eliminated the pores (figure 1). The total thickness of the laser melted zones lies between 350 and $630 \mu \mathrm{m}$. 


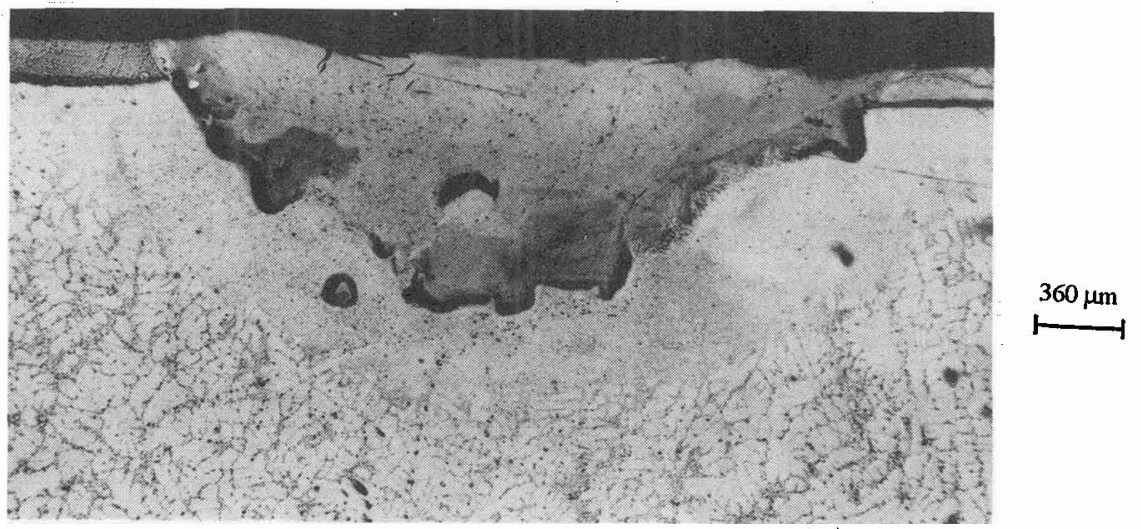

Fig. 1.- Macrograph of nickel coating on AI-Si alloy with an area melted by three laser overlapping passes with a rate of $50 \%$, preceded by a 5 hours heating at $500^{\circ} \mathrm{C}$.

\section{III.2. Microstructure characterization.}

III.2.1. Preliminary heating at $500^{\circ} \mathrm{C}$ without laser treatment.

After heating the specimens at $500^{\circ} \mathrm{C}$ in an Argon atmosphere furnace for 5 hours a diffusion area appeared. Inside this area two distinct zones between the pure nickel coating and the Al-Si alloy substrate can been observed (figure 2). The first one being next to the nickel deposit showed a rather uniform thickness of about $5 \mu \mathrm{m}$. The second one being close to the substrate showed a non uniform thickness varying between 10 and $20 \mu \mathrm{m}$.

Figure 3 represents the Ni-Al-Si distribution versus depth carried out by means of energy dispersive spectrometry (EDS). The w/w ratio of Al/Ni calculated within the $5 \mu \mathrm{m}$ of the former zone was 0.22 while within the $15 \mu \mathrm{m}$ of the latter zone the above ratio was 0.60 . According to the Al-Ni phase diagram [5] AlNi and $\mathrm{Al}_{3} \mathrm{Ni}$ phases were identified for the 0.22 and 0.60 ratios respectively. Silicon diffusion is found to be negligible and this is attributed to its inclusion into the eutectic areas of the substrate.

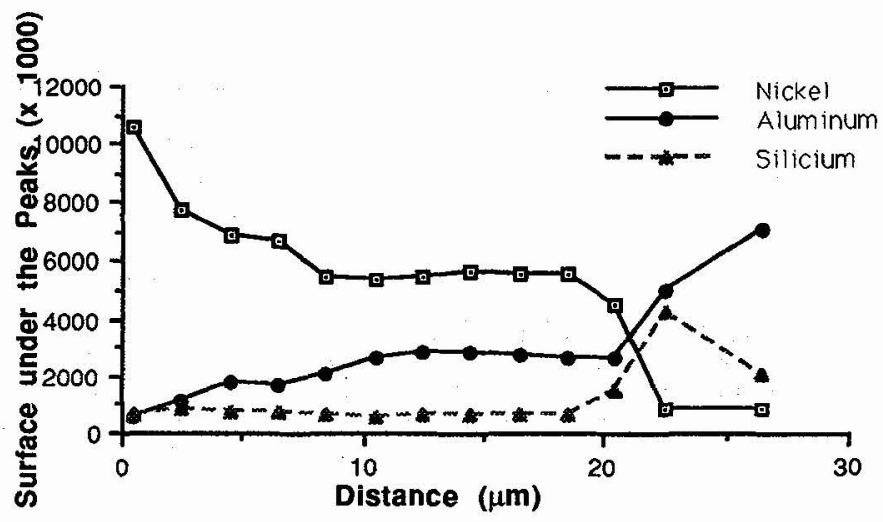

Fig. 3.- Ni-Al-Si distribution versus depth carried out by means of EDS.

\section{III.2.2. Laser melting without preheating.}

After laser melting treatment, either through a single pass or successive adjacent overlapping passes, without preheating, the microstructure of the laser melted area is characterized by two distinct zones (figure 4).

$X$-ray diffraction analysis (XRD) was performed on the upper zone of the laser melted area. This zone was found to contain $\mathrm{Al}_{3} \mathrm{Ni}_{2}$ as the main phase as well as AINi phase and $\mathrm{Al}$ in small percentages. The upper zone was removed 
by polishing and XRD was performed on the new surface of the lower zone of the laser melted area. In this zone $\mathrm{Al} 3 \mathrm{Ni}$ was detected to be the main phase while AlNi phase and $\mathrm{Al}$ were found in small percentages.

The $\mathrm{Al}_{3} \mathrm{Ni}_{2}$ phase had a globular form while the $\mathrm{Al}_{3} \mathrm{Ni}$ phase had a very fine dendritic form with an interdendritic space of 1 to $2 \mu \mathrm{m}$. Both $\mathrm{Al}_{3} \mathrm{Ni}_{2}$ and $\mathrm{Al}_{3} \mathrm{Ni}$ phases were found to be contained in a matrix consisting mainly of an aluminum solid solution and to a lesser extent of the AINi phase [8].

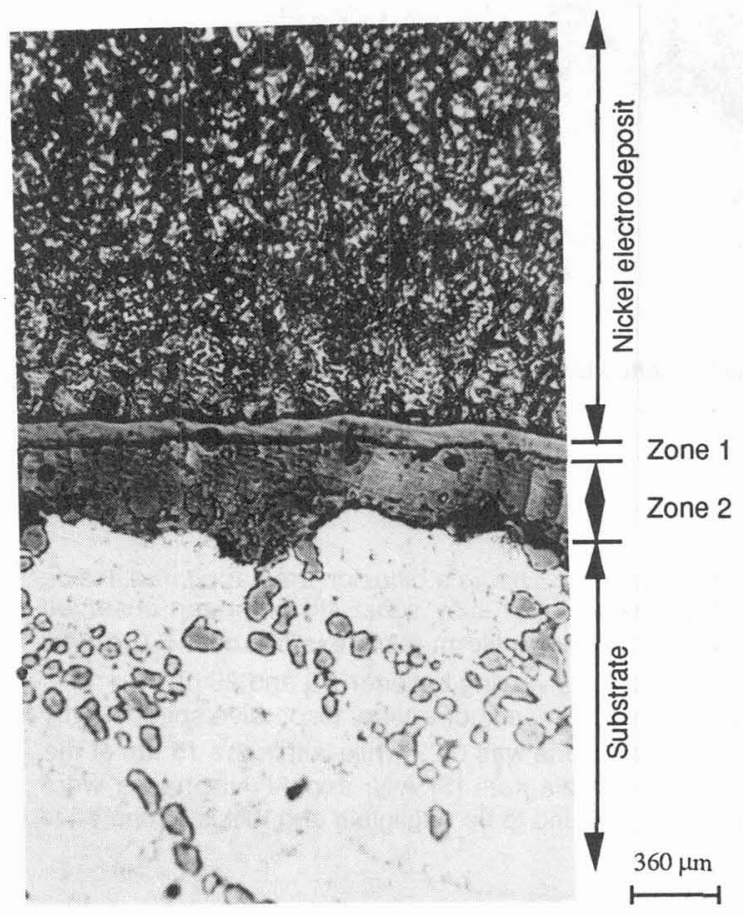

Fig. 2.- Microstructure of the diffusion area after a 5 hours heating at $500^{\circ} \mathrm{C}$. Etching by $\mathrm{HNO}_{3} 50 \%$ w/w, $\mathrm{CH}_{3} \mathrm{COOH} 50 \%$ w/w.

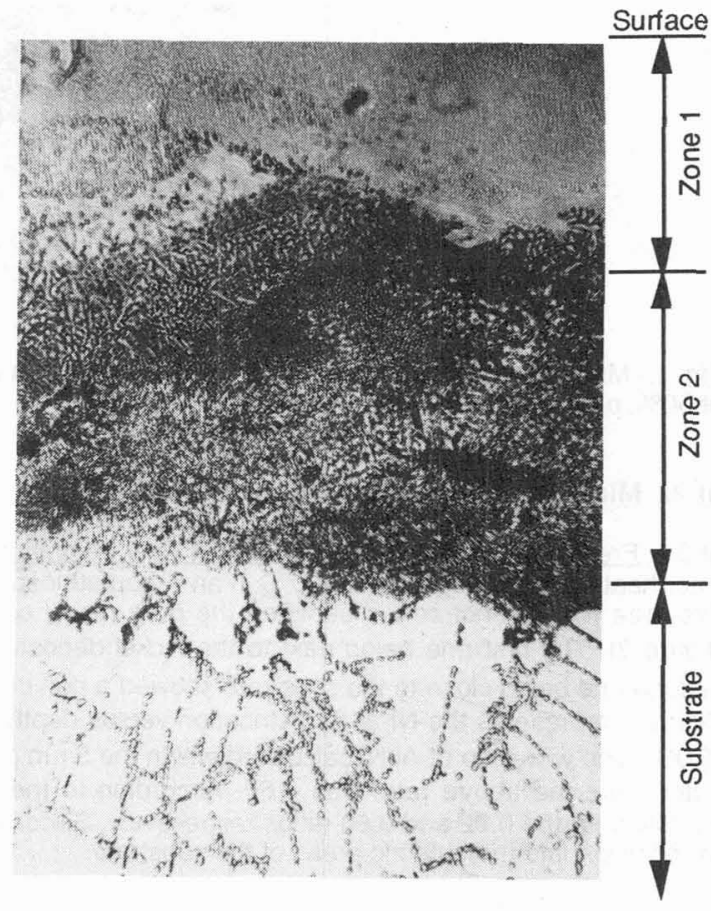

Fig. 4.- Microstructure of nickel coating after laser melting process and Al-Si alloy substrate.

Etching by $\mathrm{HNO}_{3} 50 \%$ w/w, $\mathrm{CH}_{3} \mathrm{COOH}$ $50 \%$ w/w.

\section{III.2.3. Laser overlapoing passes preceded by heating.}

When the specimens were heated at $500^{\circ} \mathrm{C}$ for 5 hours and then subjected to successive adjacent laser overlapping passes the resulted melted area consisted of one single zone (figure 1).

$\mathrm{XRD}$ showed that in this zone the $\mathrm{AlNi}$ was the main phase while $\mathrm{Al}_{3} \mathrm{Ni}_{2}$ and aluminum were also detected in low percentages.

\section{II.3. Microhardness measurements}

Figure 5 shows microhardness measurements as a function of depth, starting from the surface of the specimen, before and after a single pass laser melting process. Microhardness increases considerably after laser surface melting. This certainly results from the formation of new nickel-aluminium phases and the grain refinement. Two comments may be attempted here: 
- a fairly large dispersion of the microhardness values occurs in the laser melted zone which is certainly due to the microstructure heterogeneity.

- a rather abrupt transition is observed in the microhardness values starting from the surface of the melted alloy and continuing through the substrate. This is due to the small thickness of the heat affected zone and therefore the range of the diffusion phenomena is also limited [9].

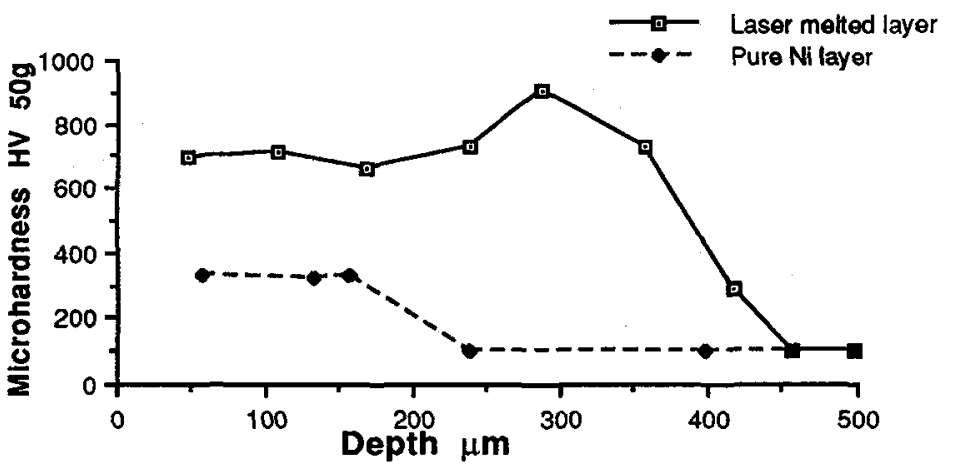

Fig. 5.- Microhardness measurements as a function of depth on pure nickel electrodeposited coating before and after laser melting process without preheating. $\left(Q=2 \cdot 10^{5} \mathrm{~W} / \mathrm{cm}^{2}, t=46 \mathrm{~ms} . \mathrm{V}=2,17 \mathrm{~cm} / \mathrm{s}, \mathrm{d}=\right.$ $0,1 \mathrm{~cm}$, load: $50 \mathrm{~g}$ )

After a laser overlapping process, in the overlapping areas microhardness values fall because of the remelting effect, during which temperature differences are smaller and therefore cooling rates are lower resulting in greater grain size and reduced strains. The fall of microhardness values depends on the overlapping rate. When the overlapping rate was $70 \%$ the fluctuation of the microhardness values had a narrower amplitude compared to that with a rate of $35 \%$ and their mean value was lower.

Figures $6 \mathrm{a}, 6 \mathrm{~b}$ and $6 \mathrm{c}$ represent microhardness measurements at a depth of $80 \mu \mathrm{m}$ along the surface of the melted zone when the laser overlapping process was preceded by a 5 hours heating at $500^{\circ} \mathrm{C}$. The overlapping rates were $35 \%, 50 \%$ and $70 \%$ respectively. In this case also the fluctuation amplitude was narrower $1500 \mathrm{HV} 50 \mathrm{~g}$ versus 700 $\mathrm{HV}_{50 \mathrm{~g}}$ ) when the overlapping rate was $70 \%$ compared to those with a rate of $35 \%$ and of $50 \%$ and the mean value was also lower $\left(550 \mathrm{HV}_{50 \mathrm{~g}}\right.$ versus $\left.1100 \mathrm{HV} 50 \mathrm{~g}\right)$. In areas showing high microhardness values (about 1300 $\mathrm{HV}_{50 \mathrm{~g}}$ ) there is a considerable risk of cracking [10].

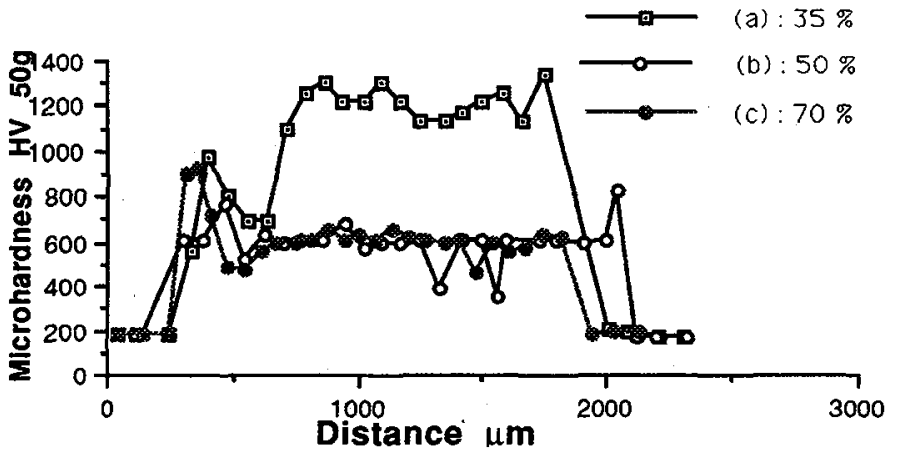

Fig. 6.- Microhardness measurements taken at a depth of $80 \mu \mathrm{m}$ under the surface along the laser melted zone without preheating. 3 parallel passes, $P=2872 \mathrm{~W}, \mathrm{v}=1 \mathrm{~m} / \mathrm{min}$, Load: $50 \mathrm{~g}$.

(a)Overlapping rate: $35 \%$,

(b) Overlapping rate: $50 \%$.

(c) Overlapping rate: $70 \%$. 


\section{CONCLUSIONS.}

1) After laser melting treatment, either through a single pass or successive adjacent overlapping passes, without preheating, the laser melted area consisted of two distinct zones. The main phase in the upper one was found to be $\mathrm{Al}_{3} \mathrm{Ni}_{2}$ while in the lower one the $\mathrm{Al}_{3} \mathrm{Ni}$ phase was predominant.

2) Considerable porosity was observed in all the laser melted zones. Increasing laser overlapping rate reduced the extent of porosity but it did not eliminate it.

3) A 5 hours heating treatment of the specimens at $500^{\circ} \mathrm{C}$, without laser melting, yielded two diffusion zones. The upper one consisted mainly of the AlNi phase while the lower one of the $\mathrm{Al}_{3} \mathrm{Ni}$ phase.

4) Laser overlapping treatment preceded by a 5 hours heating at $500^{\circ} \mathrm{C}$ yielded completely pore-free laser melted zones consisting principally of the AlNi phase.

5) Microhardness values were considerably increased (at least twice) after laser melting treatment.

6) The narrowest amplitude of microhardness fluctuation as well as its lowest mean value were achieved when a laser overlapping treatment was employed with a rate of $70 \%$.

7) Finally a laser melting treatment by successive adjacent laser passes with a rate of $70 \%$ preceded by a 5 hours heating at $500^{\circ} \mathrm{C}$ yielded best results concerning microhardness, microstructural homogeneity and porosity elimination as well as adhesion of the Nickel coatings on the Al-Si alloy.

\section{REFERENCES}

[1] F. A. Lowenheim (ed.): Modern Electroplating, 3rd ed., John Wiley and Sons Inc., New York, NY, 1974, p. 592. [2] L. J. Durney (ed.): Electroplating Engineering Handbook, 4th ed., Van Nostrand-Reinhold Inc., New York, NY, 1984 pp. 155-56, 168-69, 185.

[3] S. Polymenis: Compt. Rend. Journées d' Électrochimie, Dijon (France), 1-4 Juin 1987, pp. 7-26.

[4] R. Marini, D. Pantelis, C. Prioul, L. Ledoux: Matériaux et Techniques, Sept.-Oct. 1990, No 9-10, pp. $27-34$.

[5] M. Hansen : "Constitution of binary alloys", McGraw-Hill Book Co., New York, NY, 1958, pp. 118-21.

[6] C. Kim, L.S. Weinman : Scripta Metall., 1978, vol. 12, pp. 57-60.

[7] L.S. Weinman, C. Kim, T.R. Tucker, E.A. Metzbowere: Applied Optics, 1978, vol. 17, No 6, pp 906-10.

[8] S. Mordike: Proc. 6th Int. Conf. on High Power Lasers ("Laser-6: Welding, Treating, Machining with High Power Lasers"), Paris, 2-3 April 1990, pp. 99-108.

[9] S. Jobez, J.M. Pelletier, A.B. Vannes: Proc. 2nd Int. Seminar ("Surface Engineering with High Energy Beams"), Lisbon (Portugal),

25-27 Sept. 1989, pp. 317-29.

[10] Y. Th. De Hosson, H.Y. Hegge: Proc. 6th Int. Conf. on High Power Lasers ("Laser-6: Welding, Treating, Machining with High Power Lasers"), Paris, 2-3 April 1990, pp 115-20. 